\title{
REPORT OF THE SECRETARY
}

UF TIE

\section{Oregon State Board of Horticullure}

\section{FORESTRY AND ARID LAND INTERESTS}

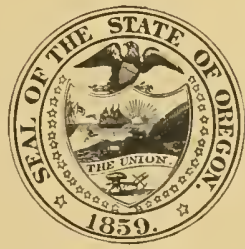

REPRINTLI BY TIE AUTIOR

From a publication of the state of Oregon in 1 kek 

A PAPER

13

\section{FORESTRY INTERESTS}

() $1+0121 \%(3) \times$

13Y

JOHN $\triangle 1$ I N

A KEPRINT BY THE ALTTHIV

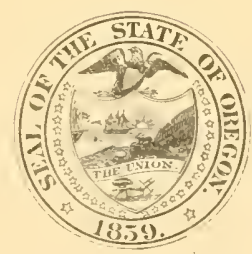

SAIFY, OREQUI:

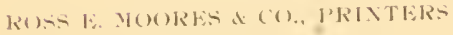
19119 
D. OF D.

FEB $\quad 14,910$

$\therefore \vdots$ 


\title{
FORESTRY INTERESTS.
}

\author{
Yr. President and Yembers of the Buard:
}

Since responding to your request in April bast to write out my views on the subject of Forestry, I have, as you authorized, hecome a member of the Imerican forestry Issociation, and from its publications and others from the division of forestry of the ['nited States department of ayriculture, and from 11 on. Binger Hermanu, Commissioner of the General land (Iffice, I have secured valuable information on the present status of the national forest policy, in which the Anericau Forestry Association seems to the an impelling and guiding intluence.

The American Forestry Association is a roluntary bouly. Its menbership roll contains six hundred and ninety names, sixty-eight being females; and three hunclred aud seventyone-a clean majority-are residents of New York, Yassa. chusetts, I'ennsylyania, New Jersey, ant the District of Columbia, fifty claiming residence in 11 ashington (ity. It is, I helieve, reasonable to suppose that the large majority of the members of this body are erlucated people-idealist: on the subject of forestry. It is not deened unreasonable to assume that the fifty members located in Washington are (in aldition to beingr well informed) either in the employ of the National Govermment, or wishing to be so. The organization is so constituted that a few active members can shape the conrse of the association and become a powerful inlluence in framing the policy of the government relative to the disposal of forest lands. Take 13. E. Fernow's position as illustration: He is chairman of its executive committeethree being a quorum; a member of its directors, four being a guorum. [And fifteen is a quorum of the association.] He is also clief of the division of forestry, which gives him a in reat personal influence. By the report of its executive com. mittee, read by $\mathrm{H}$. Fernow, February $5,1 \times(97$, we are informed that it secured the appointment of a committee of the National lcarlemy of sciences "hy influcing the then secretary of the Interior (Hon. lloke smith) to ask the adrice of that learned boly." as to the proper steps to be taken with reference to the public timber hands; that an appropriation of $\$ 25,040$ was readily secured to pay its expenses; that "it was nut expected its recommendations would be 
essemtialls or strikingls eliferent from these mate amel anlocatel he the issinciation;" that it was hoped "the weight of the opinion of the cmment men of the committer, so secured, and the botly trom which the committee was selected-being the legally constituted alvisor of the government in matters scientific-would do much to aronse more serneral public interest and to secure the passage of desired legislation." Ja the same repurt the committee mentions that "it pasated and directed to congress and the executive, resolutions protisting against the modification of the cass catle range turent reserve, which moditicaton the peojsle of () regun latil petationcel for."

The report of the execolive commates of the American

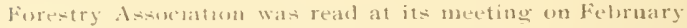
inh. lliat al the ammitte whose appointment it secored

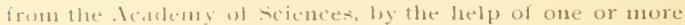
competout cleth- ot the sernetal land office detailed by secrelary fram is fo assist in its prejaration, lad been "comphotud am =ubuntecl about February 1st." It recoumended lisirnen arlatumal torest reserves, of an agrgregate area of $21,379,2011005$. The recommendation was adspted and pro-

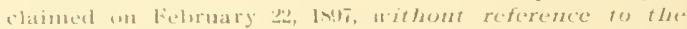
represelutitides of the states mest directly interested or

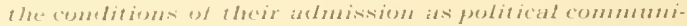

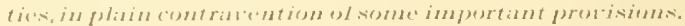
The report is antroluced hy alluding to experiments now moler frocess hy fillatave $1 \mathrm{Wex}$ an emincont engineer having charece ol improvements on the river Danulue, griving valages recorded an to the bight and low water matks of ten river - having llecir sources in eestral Europe. As the exandintions are incomplete, they are inconclusive as to central burope, and eon-titute simply an introbluction to the report, which secens to aroil scientitic denomstration, 10 fleal in assumption of facts and aspersions of industries in tregun which cantus be iruthfully applied (o) the natural conclitions existing in this state, nor to the actions of its citikens.

llappily, the report show-such a back of statermanslip? that it cansecl a halt in the moveruent of the policy which

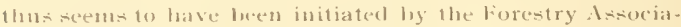
toos, the crenctal whjects of which are certainly worthy and very important where thater is neeted. The wording of the refurt of the commutlec to the Academy of aciences is such,

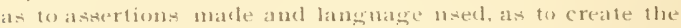
suspicion that the committee trusted too nusch to the clerk or clerks the secretary of the interion placed to their assist- 
ance. Assertions of fact are made and expressions used relative to sheep and sleep husbandry that may he passed over as emanating from an appointee of President Cleveland. It is not possible to believe such assertions and expressions to be the composition of any member of a body selected from the American Academy of sciences, and the letter of l'ro. fessor sargent, in appendix a of the report, is so superior as to make it almost certain the members "signed a report none of them would have written." The teute of the report is so almsive of sheep anul slueep owncrs as to create the ennviction that it is the product of personal animosity, an it is but a refined echo of the western cuwhoy's abuse of sherp and sheep owners-his successful contestants for grass in the range conntry. The effect of this part of the rejort will the to increase and encourage animosities which luave caused the ontrages against law and justice that have been connmitted against flock owners and their flocks in every range state. It is not intended to claim that sleep men are not sometimes aggressors in these troubles: they are not angels.

The use of the word "momadic," as defining this morle of sheep-keeping, is calculated to give a false conception of the pursuit. The owners are not "nomads," nor are their flocks, indeed. The former have their settled homes in the dry pastoral recrions of the range states-are themselves the eyuals of other men engaged in developing their localities, both in puldic spirit and private enterprise. This fact can be proved by looking at the devlopment of a comntry mach more closely resembling that claimed to have been examined by the committee than does that of central EuropeAustralasia. But Instralia, and the Jessons to be derived from Anstralia's enterprise, in the conservation of scant water supply, its records of rainfall, its experiences of the eucroachment of "pine semb" upon sheep and cattle ranges, the greater success of the former on driest ranges as coml. jared with the latter, has received no notice from this intelJigent committee. Why? It would seem as though llework was already cut out for this respectatule committee-as a stalling horse to the forestry association; and it came very near telling by whom, when it follows John Muir and 13. F.. Fernow in holding up to the secretary of the interior, and thromgli him to the president of the Lnited States, the examples of the imperial governments of (iermany, Russia and British rule in India in regard to torestry; as though the citizen-hip of the Cnited States were on the same level as the laboring populations of those countries, and there 
were no arrement between the states and the nation in the way of its resemmentations.

The committer comments the nse of the army to guart these reserves, now ageresating waily forty million acres, needed, as it clasins, lor the preservation of the water supply in the dry infuriur; and as a means of making money where the best timber is:mel water is not needed, as in the Olympie rangein 17 ashing from pasturace within these reservations, as destroyers of the forest ams desulator of the plains. The herders are singled oul at incendiaries of foreste. The major reasons for its recommondations are that forests protect the sources of streans in mumbin and lighland distriets, hy preserv. ing the snow trum melting and imperling the percolation of nelted snow or rain from reaching the vallegs beluw. Vy observalion teas lues me that momutains and lighlamelsare

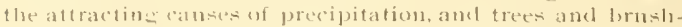
wosel are effects of this precifoitation; that all wher fhings leeing enfual, smow melts first in belts of timber or brosh,

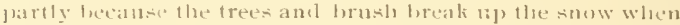
falling and partly becanse of the inflarence of eolor on sular rass, clark whjects absurting, white, relleting heat. The bulletin (Xo. Bat of the experiment station of the laversity

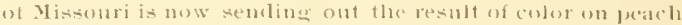
trees, showing that the simple act of whitewashing this sensitive tree delayed the swelling of 1110 buds twenty-two lays lafer than the unwhitened. This areords will my oluervations en the ciscoule rangere, where it is rate fo fiml a patele of snow within the timber after the midllle of July,

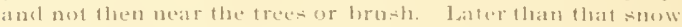

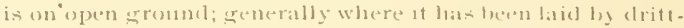
ing. Tlese snow banlis on spen land, and walter from springs in vallege below, are the sompees of rivers atter the mitdle of July:

Congress, in passing the snmely civil expense hill, June 4, 1sit. provideal for the survey of the forest reserves, allel empowered the prosident to revoke, modity or suspenst all soch execolise orelers or proclamations, or anv part therest, from time to time, as he shall cherm best for the jublic in-

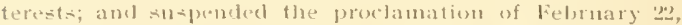
lati, as to reserves in Wyoming, Ttals, Mentanas, Washing-

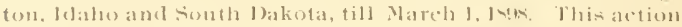
las hat the result of (ansing the departuments of the interiur

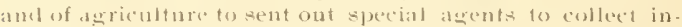
formation on the interests involved. Yr. F. L. Coville, botanist of the department of agriculture, visited this olliere 
with a letter of introluction from Hon. Hinger Hermann, asking such aid an 1 could grive him as a special agent of the department of ayriculture, sent touregon with a view of studyine and reporting upou the sulpject of sleep crazing witlin the foresl reserves. I gave him all the aid I could and a creneral letter of infroduction to -urh stockmen as lac should meet on his proposed route nortliwa rel from Klanati Falls on the summit and eastern slop. of the Caseade range.

In a letter from Wishington, ackuowledging my letter was a service to him, he expresses the belief that he hat wathered facts whith woubl solve the grazing dpuestion.

A letter from Edwin F. Smith, stasti-tieal acent of the dejartment of ayriculture, asking the number of sheej anct value of errazing on the Cascarle rance and fort-lulls, was received by Hou. II. L. Mosels, of the lirst district. Who turned it over to me for answer. Based on the number of sheep assessed in Wasco, Sherman, Crook, lake and lilamath comnties in fortand estimating the number of laubs not assessed, I count the total 716,630 thead, the wors yield of which l estimate at 4,9sisthin pouncls, worth in the home

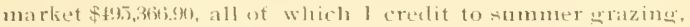
leaving the anton and lamba to the credit of winter care: but 1 think the benefit of the sheep being taking off the plains in summer is worth fully as much to otler stock interests-horses and cattle and to the wintering of sheep, so that the total value would le in rotud number $\$ 1,0(1,04(4)$ annally. Only one-third of these sheep as yet go within the bounds of the reserves as laid, hut the number is increasing as the thockenters increase and improve their provisions for the winter lieep. There is liftle or no lumber taken from the reservations. The provision for winter feenl is the engrossing sllmmer work of the eath ()regon flock onner, and his success in that is the measure of lis sllecess in his pursoit. In this be las the aclvantage of the range catte owner, as he has lis lbocks al way under control, which is well nigh impossible with cattle or horses. Cattle, horses and fat sheep are crenerally shipped to markets east of the Rockies loy rail, hut sheepdesigned for sale as breeders for the ranges of Wroming or the lakotas, or leeders for the corn lands of Nelraska, Kansas, or adjoining states, are driven on foot, perferably on the highest lands on the route taken-both foud and water and avoidance of local interests being considered. The lorestry committee, almuling to these in terests, says:

"Great llocks are winlered in the sheltered canyons of suatie river, and then, spreading throngly eastern Oregon, 
labe destroyed the herladge of the valleys and threatened

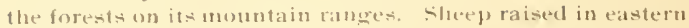

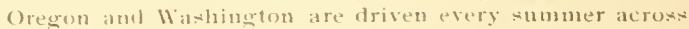
daho and Wy yolning to marliets in Vehratia and Jakota, eating hare at thes go ancl carrying ruin in their path. In every westeru state and territury momadie sheep men are Irealed and despiates. Vear after year, however, they con-

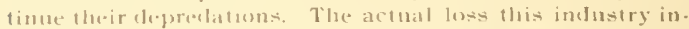
flicto on the comuty annually in thousands of acres of burmt timber and an ruined pasture lands, is undoubtedsy lastere, althengh jusigniticant in comparison with its eflects on tla future of monutain forests, the thow of streans and the aldionltural pusthilites of their valleys."

This extrace entains the chief points of the commitlees

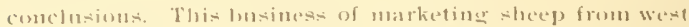
of the Rorekies is in lise hands of mildle men, who paly for any acoumumblations they receive from residents of the comutry thes crosis. Tlue picture of destruction is wholly

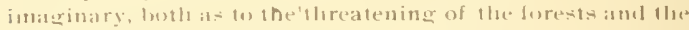
ruin wh pastutes. I lare insert an extract from a letter re-

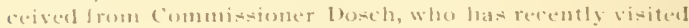
the suake riser canyons. Ile tays:

". - you know, I have just returnet froma trip to Yontana and incilentally paid a visit to fritels in ['tali, ldallo, amel ()regon, afone lde snake river, examining many commereial and private orelateds all under irrigation. I have eome to the conclusion, nutwithstanding the fearful beat for it rangeres

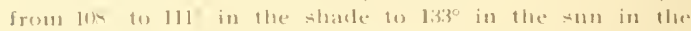
orchards, anriculture and lowrticulture is much more satis-

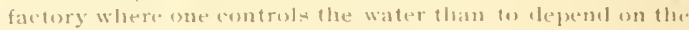

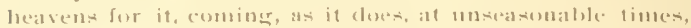
which is not the ease in irrigated distriets. I have not ser.l liner kept orclaarts, nor more thrifty erewing trecs, nor

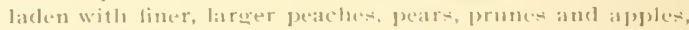
than those very orchards along snatke river, which were lont

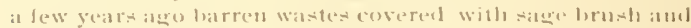

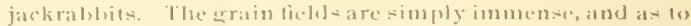

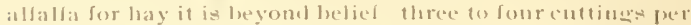

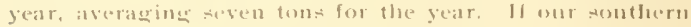

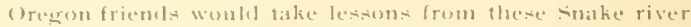
people, they womld sisuply hase a paratione."

In a more recent letter Vr. I losels tells me of one lim near

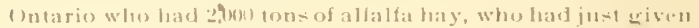

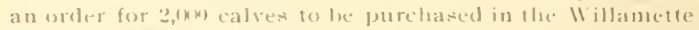

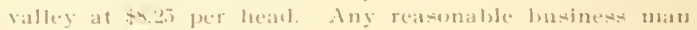
kuowe that this transunumtain trate in cattle and sheej is 
one of advantage to breeder, middleman and feed-seller; and so far as the sheep are concerned they are not "hoofed locusts" but the golden hoofed hearers of the golden fleece, eating a greater variety of the bitter weeds of the lot plain, and by their owners carrying gold to the owners of hay in the Snake river and other canyons, when their welfare demands such purchase. They do not eat coniferous trees at any stage of irowth, and they lesisen the danger of forest fires where they feed. This is the statement of unprejudiced men, from central California, fo northern [3ritish Columbia on the Pacific coast. In the consular reportsfrom Anstralia, which tell of sheep being destroyed in fires of dry grass and timber combined, there is not a single cluarge made against sheep keepers as incendiaries.

Among those who have been liere this past summer to estimate the reasons for the people of oregon desiring the reduction of lle Cascade forest reserve, wa - Yr. H. E. Fernow, to whom allusions have been made. If his remarks relative to the Cascade reserve were correctly reported in the oregonian of September ath, it onght not to be hard to convince him the people of oregon are riglit in their desire for its re. duction. They, like the people of many other states, are very willing to have some of the nost interesting momntains included in reserve parks. Ife ascended the bases of Yt. Hoodand Yt. Jelferson and made an estimate of the reserves as a timber resource. To rach the latter momutain he passed throngh a community of a larger number of citizens than constitutes the American Forestry Association, whose families are supporter by humbering interests inside the reservation. He is reported as saying: "There is not much, although some, good matketable material on the Cascade and Bull Run reserves, but the larger part of the great reserve, I am inclined to think, comprises Alpine furest of hemlock and firs, which does not furnish material at present marketahle, or else is hurnt up. Althongh the reserved area appears large, its usefulcontentsarelut scanty. You may safely halve the area as far as serviceable timber is concerned." Tluis is a remarkably gool estimate of the eastern half of it, but Mr. F. was deceived as to the west half by seeing only the ligh ridge, whereon the timber is always thin and inferior from natural causes-foremost of which is lack of moisture at its roots; next, the injurious intluenct of the wind.

Mr. F. proceeds: "I lave not heard a single good reason against the reserve. Tlie reasuns usually can be sifted down to some small speculative interest, that is supposedly 
siterilieed to the arteater eommunal inferest. The pow man who das taken 11 , a homestead in the words-not to make a home, lont tospeculate with the timber on the lixh acres feels infured because his speculation may not pan out; the

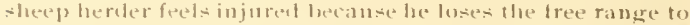
which he harl hardly any right before, and which he elid his letst to chestroy by his reckless manner of using it; a lhird chass is formed by these who (on-ieler the reservation poliey one impused npun western communities by eastern cranks. iemorant of western comblitions. These are to be pitied for their lask of perception that this i- one ceontry with oue in. terest, kowwing no calot and no west." In this, Mr. Fermow

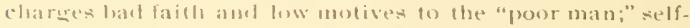

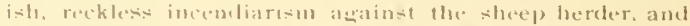
narrow, sectional jealonta ananth thoke who oppose the reserve policy This is "one conntry." but there are sup. fuset to be alsmt selenty millions of personal interexts coseret by its constitution. There are some forty com. munily interesto lewally formed, which should not $1 x$ lightly intringel. The eitizenship of the fonrteen states ami ferrifories which have larege amounts of pullie lands wilhin lheir bounds, and of which llacy have heretufore been deromed the lowal groardian- moler tlae ferms of their admision to the moion, preserves a full average share of pricle in the fact that this is a govermment "of the people, by the people, and for the perple." which secures to the poorest eiti. zen the ownership of himself, and may be sad to invite him, by the homesteal law, th the ownership of a home. As one of these, the writer claims llow right to be heard in reward to this resterve peolicy, as it hears upon the interests and sectus f1) threaten the liberties of entizents of (bregen, for reasunc

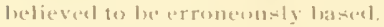

With dine respeet lor the members of the leorestry . Issocia-

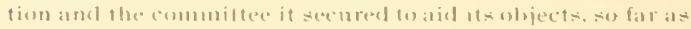

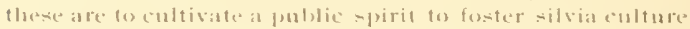

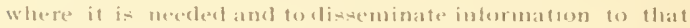

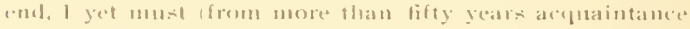

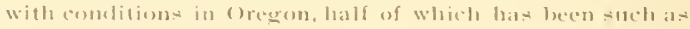
to make me familiar with the natural plenomena of llate

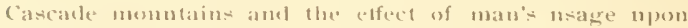
themblisent afmost in fosto froms the assumptions of the commitfere and the derogatory charges mascle against sheep, thes herclers or their owners. I owe to the nation to alatel for the truth on this subject in all it phases, greneral as lo foreatio and conservation of water supply, and particular as

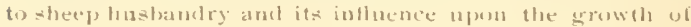


conifers (the only forest trees of the Cascade range and interior momntains involved in this policy, except a little cottonwood and aspen.)

For two years prior to March 15, 1893, I was in the employ of the [nited states department of agriculture, to examine and report upon the condittons of shese husbandry in the states of Califormia, (Oregon and Washingtom. The condensed report is published in the special report on the sheep industry of the ['nited States, burean of inchustry, 1sy2. Ten letters of California sheep wrowers are therein quoterl, all protesting ayainst the charges of setting out forest hires by sheep herders. They are samples of scores of letters of the same tenure, from which I gathered that, wuless fires were started cesignedly by the hasque herdsmen (who were really nomadic in their methods and had barwely superseded the Americans in southern (alifornia) the charge was untrue against the sleep industry in that state. It llever had a particle of truth in it as to the state of (Mregon, so far as 1 know, nor in Washington. In British Columbia, the most recent government reports contain thirty-seven answers, viving canses of forest fires. Not one mentions the sheep industry as being the canse, yet there, as in western Washington and Oregon, the clearing of thinly set timber lands for lomes, in which sheep can he ntilized to some extent, is increasing as population increasts.

Mr. Fernow is quoted as saying that the smoke he found an annoyance in Oregon will deter tourists from visiting this state. Well, Oregon as a community hat not yet conse down to the show business. The snolie is not the evidence of forest hires ly incendiaries. It is in the main evidence of burnt offerings to natures cout by the home huilders of western (Oregon and Washingtwn, who believe that:

"To make a happy fireside clime For wean: ind wife,

Is the true pathos and sublines, uf human life."

Sometimes fires get beyond the control of homebuilders, though not often. Carelessness of summer vacationists, hunters, herry-pickers, travelersthrough unsettled mountain timler districts, and road makers, is the most common canse of forest fires. The Hon D. P. Thompson, who has had great experience in the timber lands of Oregon as a surveyor, believes he has knowledge of two instances where tires occurred spontaneously, probably by the rays of sunlight shining through clear turpentine exudations. This 
mal account for some fires on the east slopes of the Cascate range where the yellow pine exules turpentine very freely. But it must not tre forgotten that the Warm Springs ludian reserve is fornded on the weet by the summit, and the Indians have the rights of hunting and grazing their ponies on the eutire rande, fo which many of them resort every season, when (by custom from which they see no reason to desist they renew the old berry patelies and coarse grasses of the dry lake heds by firts

1 would estimate seventy five per cent. of the smoke ol. scuring the views of the september visitor in Oregon or Washinetom as the remult of land-clearing for homes. The employment by the state of five or six active young men from the first of July to the last of Octotuer of each year would som stop, four-tiftis of the fires resulting from carelessness west of the summut of the Caseade range. They are very rare now on the east side, and though ten years agn they were wor. frepuent, they never were destructive of valuable timber, becanse tlev grasses, even when dried intu hay, were always light within the timber helts. Pasturagre of stock is a protection there, as fifty year's experience lats provel that summer grazing prevents dry grass hires in western (Oregon and IV ashington. If it were desirable os (onserve the forest growth it coubld be done by selfing the land, or leasing it, on defined conditions, as is elone in the Anstralian colonies. where men of weight and inlluence arte not in the labit of making war upon the most important in 1 dustry possible in a conntry clusely resembling these range states; wherein there ars yet (although grants, reservations and private ownerships cover mearly all the water eomreses exelumive of Texas, Ji3takl, (k) ateres of puthlic lancls, of which Oregon has $35, x+3,31$ a actes. (ive the persple of those dry plains the wise lilemal induesuents and security in their insestments which have heen marle for sheep, cattle or horse breeding in Anstralia; and in adflition to sheep lusbandry

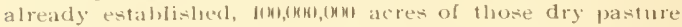
lands will beconte a field of protaction which will feetl the looms of the nation, without the necessity of importing a pound of woot, and in adklition will supply lamb and mutton to the people:

senator II a rren, of II yoming, in a paper in The llhwatrat American, estimates the mumbers of livestock now feeding in the arid land - tates,and ranginge the lly on the pablic lands.

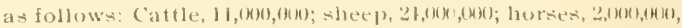
mules. so,onk. Itncler our exiating land system, the contest for range privileges to which no 11 an his an exelusive right 
leads to rivalry and strife which not infrequently culminate in lawlessness and hloudshed. Cive leases to applicants on nominal terms, or sell, under conditions, at very low rates. securing to those making permanent improvements in either case the appraised value of such inprovements, whether on the plains, parched and dry, or on the grassy highlands, which are a haven of comfort for ma: and beast in the stm mer months. From all the ranere combtry at elevations pro. ducing the pine trees, timber and water will be carried to and conserved on the plains, and timbar preserved on the mountains by local energies, guicled and impelled by personal and local interests. Donthle the number of cattle, sheep and horses will he kept, and helter kept than now; and lands now deemed not worth the purchase will furnish homes for thousands and tens of thomsands of happy people -lands on which yet the wood growth is sare brush and the permanent live stock, jack-rabbits. The lease and eon. ditional sale system in use in Australasia induced tloe change from loose herding to the Paldock system of keepins stock, and one-third none stock is letter kept, and at less cost, it is claimed, on the same area of land than musler the former method. What Anstraliansean flo, Antericanscando.

In the national report on sheep, to which I have referred, will be found a letter of J. Parker Whitney, another kind of baston man, who sent his brother to Anstralia in $18, \bar{s}$ and

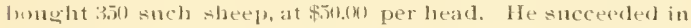
setting 12u of them to California, which he subsecpuently estimated as paying him fl, (hk),(h)o. They induced him to buy 20,006 acres of the then cheap lamel in l'lacer tomnty. Calilornia, which he was selling in small parcels in lxog at $\$ 1.30$ to $\$ 3$ A per acre, for peach orchards. This was near Rexklin, from which district be was the first man to send a train load of peaclues east of the Rockies, and where 1 saw the central Pacilic railroad company, and private parties clearing lands of the pine and otler scrub which had grown up on closely grazed lands within the past twenty-five years, just as it has done in Western ()regon.

The estimated area of forest land in Oregon has been consiclered at about $11,0(k),(x)$ acres in the entire state. Dr. J. R. Cartwell. Commisioner at large of the state lioard of Horticulture, considering the econonical values of the conifer. w1: growtl of commercial value, estimated it at li,000 square miles, or $10,(k) 0,0(1)$ acres, in 1943 . This estimate $\mathrm{Mr}$. A. W. Hammond, of Wimer, Oregon, vice-president of the Aneriean Forestry Asmociation, adopted in his report to that trody in lath. He puts "the merchantable timber on the 


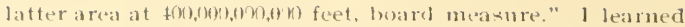
from the Oregonian, that Yr. Hammond, was the first to publish these estimafes. He says: "The anmul out-put is

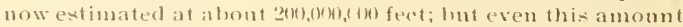
must he insignifiont in conparison with the anount an. nually wecaying and in a sonse crobug to waste in tlue foresto thromigh natural ianses. In many places, even abont the seltfements, une will sec numbers of the very largest and handsommt pine trees-in esery respect ungnificent specimens-201 to 2.50 years okl and more, deas and dying, that in 11 at go th waste becante of the entíre absence of means of converting them intolumber.

"The anmual ont-put, in fact, represents an amomnt equal (1):abont lif per cent, only of the annual grewth. Whence it follow (if the furet remains stationary) llat an amonnt effual to kl per cent. of this new arrowth is annolly guing to waste. This moans, in other words, that if the mature limber could heculled anually from the forestas of this state,

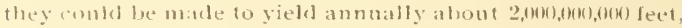
board moasurement, withost detriment."

I quote a fittle fartler from Yr. Hammonel to show low impractical a good man can he. He saysa: "In the opinion of llue writer, what is most needed here just now is, first. some eflicient regulation in regard to forest fires: secomet, proper meastures 10 prevent the gobluling $a$, of lare $t$ racts of the most valuable portions of forests ly private corporations where lumbering operations are liable to be carried ou withont reference to funte needs of to future conditions of

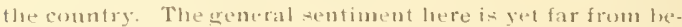
ins sulliciently alive on this impurtant subject. So many interesta wathl like to share in the general prosperity that that wonld follow the working on any arlecpuate seale of the crreat foresto of this stalte, that public sentiment, it is muly toos well feared, would be in sympathy with any movement of that kind, and the future needs or the future condition of the conntry would receive no atfention except at the handsof a rew:"

How reatful the mentas condition of a man must be who

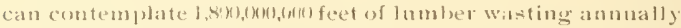
for lack of users, yet lot the waste (which is ome hundred fobl more than anmual destruction by forest tires) wo on fur fearofover-cuttimy in a country liketlia. The writer areatly prefers to meet fresent homan interests, and is very ghal to belicve the people of ()legon are of tlue satme mind in very larege majority. They are proving this by the very wrat 
increase in the lumber cut since Yr. Hammonel wrote down his estimates and his fears.

The enterprise of the manasers of the Oregonian has given us the lumber cut of 1597 . Beliesing they will be interest. ing reading to ideal foresters and fricmels of forestry for $j$ ts nees to humanity, I insert 1 wo papers relative to the suloject

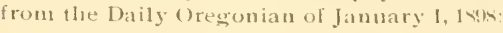

\section{LITYBER C ITT.}

"The saw mills of (Orecon cut $.34 ! 9,823,17$ feet of lumber last year. By countie- the cut was:

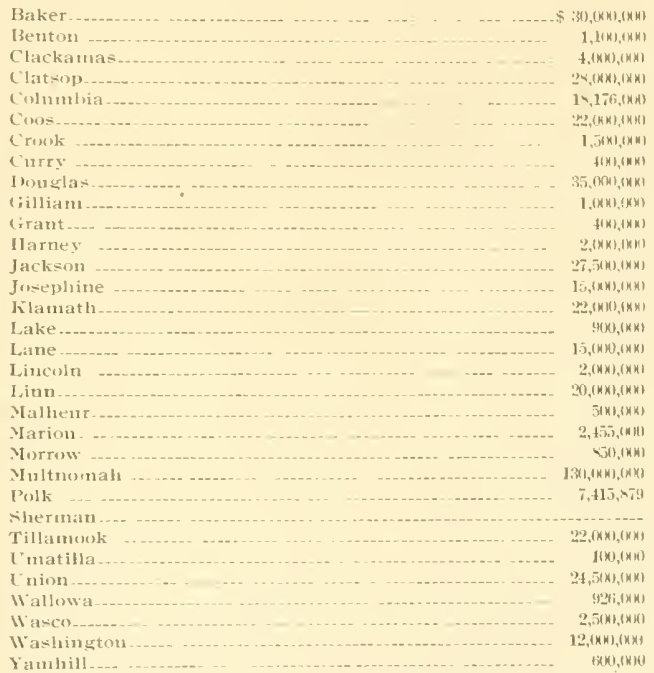

"The mills of Yultnomah connty cut 130,(x), (8)(0) feet, valued at $\$ 1,(0+1,(H))$, an anerase of $\$$ per thonsand. The same average applied to other counties, brings the value of the cut in the slate to $\$ 4,3$ ! $9,5+5.5 .43$.

"Oregon's timler supply is practically inexhanstible. The great belt, comprising the commties of clatsop, Columbia, Washington and Tillamork, contains, as is set forth in another part of this paper, approximately $56,(0), 0(0), 000$ feet of standing timber. Last year the lmmber cut in the four 


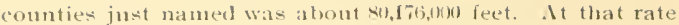
it will take nearly 7 (x) years to exhaust the standing timber in the belt.

"Yulnomali comnty cuts more lumber than any other country on the lacilic coast. Portland cuts more lumber than any other city on the Pacific coast. She leads the l'acitic northwest in lumber as she leads it in every other com. modity. As l'orthan is sitmated close to the world's greatest timber belt, there is no likelihond that she ever will lose her position as the ereatest lumber-manufacturing city on the Pacitic coast indelopment of the great belt, which muat take place witlin the next ten years, will make l'ortland the yreatest lamber-manufacturing city in the world."

THE WURLD'S GREATEST TIMBER BELT.

(bregunian, January, 1, I*!4.]

The wrontest timber belt in the world is in the connties of Clatsis), II ashington, Colnmbia and Tillanuogk, in Nortli-

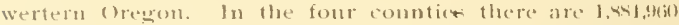

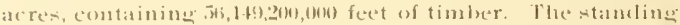
timler is worth on the average 50 cento per lono feet, fuaml

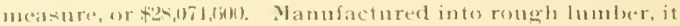

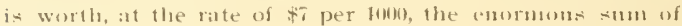
$\$+3 ! 33,1117,1111)$.

("latsop county has alont 5i30,0)(3) aces of timber land,

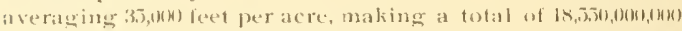
fict.

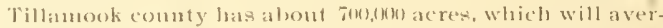
age $3.5,1$ h

11 ashington county has about 2 isistith acres, which will

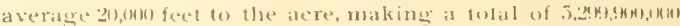
fert.

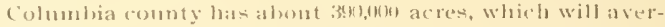

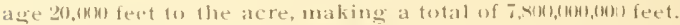

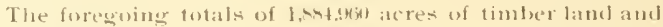

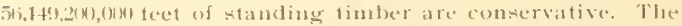
majority of people who higure on Gregen's available timber supply base their calculations on an aseriuge of 10 , $0(1)$ feet per acre. The average value of 50 cents per $1,0(k)$ feet for standing timber is reasonable. Present prices of stmmpare

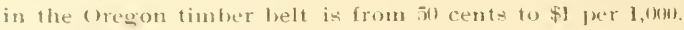
Government forestry experts have placed the average for ()regon at is fents per 1 , (kul feet.

The principal rivers in the timber leet are the Sehalem,

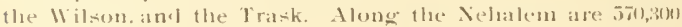

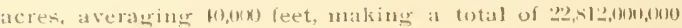


feet. Along the 11 ilson are 111, thl actes averaging $35,(x)$ feet, naking a total of $3,907,4(k)$, mo fect. Along the Trask are

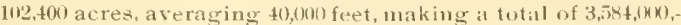
$0(\%)$ feet.

The timber in the belt consist of fir, cedar, hemlock, spruce and larclı. The fir is the gennine yellow or Donglas lir. It constitutes per cent. of the entire arowth. Timber in the belt is less subject to fire than timber in any section in Oreyon. This is becanse the lands mope toward the occan, and the lieary fogs which prevail in the smmmer keep the leaves and underbrush so damp that fires cannot take fold.

Michigan and $W$ isconsin Jumbermen of la rge capital own immense bodies of timber land in the helt.

This -lowing of forest wealth in the five comnties in the northwest comer of the state of ()regon will be arreable reading for her citizens, and a study of the question of natural supply of the entire state will leacl to cudorsentent of the worls of the Oregonian that it is "practically inexhanstible" if our fellow citizens of the American Forestry. Association can be persuated to refrain from such methods of procuring legistation affecting their fellow citizenti on this side of the continent-the conditions of whom they cannot understand sufficiently to justify their medelling, by open action or secret intrigue, obstructive of the moxt ecomomical mode of harvesting this erreat source of natural wealtli. Information derivel from the assessor of (latsop county enables me to confirm the statement of the ()rego. nian. that "Ylichigan and Wisconsin lnmber firms of large capital own immense boclies of timber in this belt. But these companies are not operating the large and costly harsesting acencies in their own timber. Why? Because the II ilson bill wave the lumber market of the world to Canada, ancl the wool market of the world to Anstralia, and these men of Yichigan and Wisconsin were compelled either to let their machinery rust in idleness or set it up near the line of the Canadian railway, and it has been employed there during the past four years, while the waste of decay lias been groing on in the wookle of (Jregon. (In the other hand, the development of ()regon's portion of the great inland empire has been obstructed by the policy alluded to and the insidions methods of the American Forestry Association, as 1 have shown.

The Oregonian's tables show the lumber cut of the five morthwestern comnties of the state to be $210,176,0$ m feet; that of the fise grazing counties of Crook, Grant, Harney, Lake, 


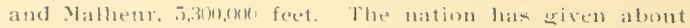

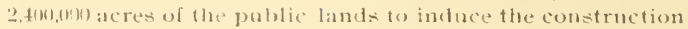
of so-called military ruals intothese comntick. Thirty-seven years agro families of the pioneer clate of citizen (w)

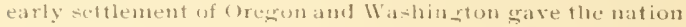
it most importint title of ocempancy to lab of the then t)regun ferritory lesand to setthe wathin the buanclary of these fise eolstues, makllly investments in full faith that

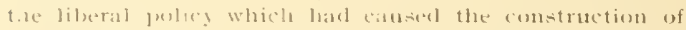

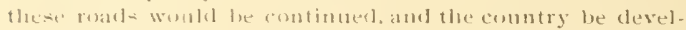

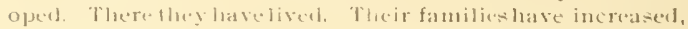

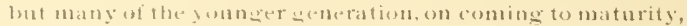
have left the isoldtun uf the pastoral life leeliand them, and

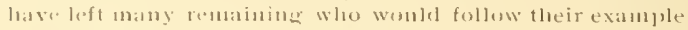
it they combl linel purellasers for their moperties. Tley

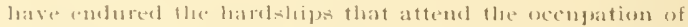
rasing cattle, Jursts, and sheep in llat resion, and the dangers inseparalise from the comtiguity of the native race. There is no lonser necessity for tle milifary roacls by which (1) g̈ive sureor there asainst Indian ugrisings. The pro-

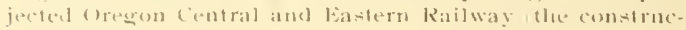

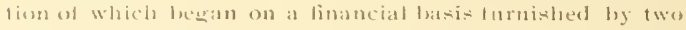

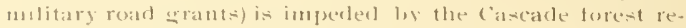
serve, This roste, if compleleted to the east lime of the state, would answer andse that atl the purpuses th the military

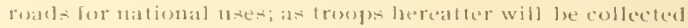
in these ratrage states of the interiur and lorought to the

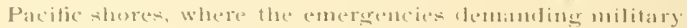
juwer are nust likely to allate. Yeanwhile the most important aicl to an increal-e of home-s in the cemtral part ut the state

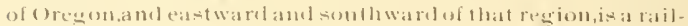

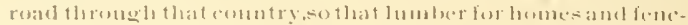
iner material, ansl fel irrigation projects, catn he distributed with areated ceomentuy. In the valley and pass by which this line of rabroacl is thow more thath hall way actoss the Cascate range there ale mure than one bundred resident homesteacler whe were located within the lomik of the tor. est reserve hefore it was proclaimed. Pany of them were

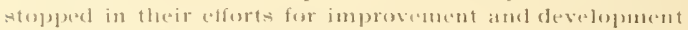

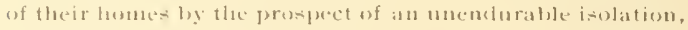

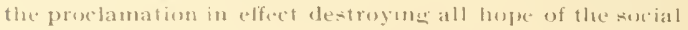

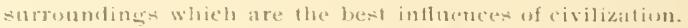
Tumpen that reservation, twotownshipa wide, to free acpuire-

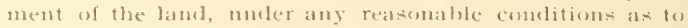

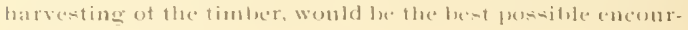
ascencht to those interested in this-rail rokel antergrise which 
llik forest policy las so far stojphed. It woulal encourage the completion of the rombl, the manufacture of lumber thromel a fine timler belt eighty miles wille, ambl quive liealthful home-supporting upportunity to al least live thou. sambl lieads of families; furnish lumber freiglits, both eastwarl and westward, of the railroat line, and develop the mumerous interests in connection with this complnatively small apening, for which many people have been wating for more than twenty-live years.

It the writer were desirous of sllagesting tle very bent means within his knowlerlge of lesentug the dangers of the

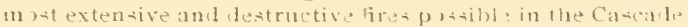
timber belt, this is the recommentiation we would make: Clear a gap across the range in the guicliost and nunt judicions way jossible. Tle committee an foretry recorded

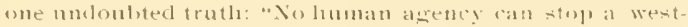

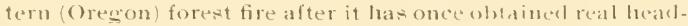
way, until it encounters a natural barrier, is extinguished by rain. or expires for lacti of material." The opening of this walp is sugrested as means of creating an artific-ial lareak in the consinmable material, and an interested resiclent popul.

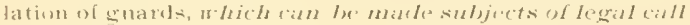

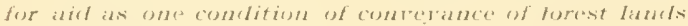
from the ration or the stizte.

Another reason for the foreguing sugerestion is the value of the witer power now rmming unused. For tifty-une miles tle forth santian river, rumbing down this valley, has an averatre and very aniform fall of fitty-one and onc-half fest per mile. It is questionable whether there is atuother strean in the state which could he su often and so chesply used in the problutaron at forece. The very refuse of its forest wealth conld tre grombl into paper pulp by waterdriven machinery. The writer as an machinist, and know little of what can now be done with electric force, Jut sincerely trelieves that in this valley there are great opportu. uties for itscheap manufacture and a convenient lield for its use in harvesting the timber growtl whirh onght to he bere saved [rom further waste, and as a guard against posible detructive forest lires. There is also, near the head of this valley, a very inviting field for frut qrowilly, flairy farming and apharies. Twenty years ago it was estimated there was rum for the settlement of 2,0 un families on open or partially open lands, upun which seedling timber has since much en(2)

In virw of this sreat waste going on in the forests of orezum generally; in view of the situations descrilued as to for- 
est and arid linds near the conter of the State, is there any reason for the pople of other states to interfere with the people of Oreson harvesting their timber wealth in their own way, uncter such circum-tances? Ah! but these Eastern friends say: "We look to the fulure and the oneness of onr country." The Western citizens will say: "Yes, but the oneness will be beat maintained by each expending bis pulsic -pirit where he know the condition." Let the citizens of New York continue to enlarge the state's holdings on the Adirondacks. late those in Massachusetts use the abandoned farms in that state for public timber lots. Let those of New Hampaluire tollow the example of Mr. Anstin Corbin, who has shown to the worla a field of interesting study by

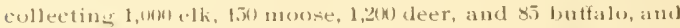
an infelinite numler of wild wine, all in a toreat park of 2 ti,th) acres, 10 form which lie canceled 37.5 titles, by purchase at from $\$$ to $\$ 2.5$ per ac re, trom people who, we maty sujpose, finci lite more pleasant in manufactures or trade of towr or eity, or in the pllke-stirring home-building of the II est, to which llaey are always weteme. In every state there are opentugs for the public spirited iclealist, or if lie does not wish to share his plans with ofluers, there is the finceximple of the fomnter of Biltmore-an imvestment in Jou, (mon acres of southern pine forests, to be managed for its forestry problucts. There are openinge for others in like enterprises in the New lingland states.

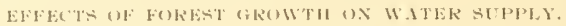

It is not posible for men and women who never saw the effect of irrigation to catimate its value uncler such eonditions as Mr. Wosch descrilese in the canyons of snolie river, and Jor. Fermow lacars witness to laving reen on the deserta of Arizona during his eximinations of the forests of that territory, recently publiahed loy the American forestry Association.)

l)r. Fernow notes that "lhe broad valley of the Rio Vercle, which carries the dranage from the platean of salt river, is capable of ascricultural development to a mach greater exfent than has been attempted, lunt, as in other parts of the territory, this requires systematic storage and utilization of water. By careful management, the cattle, sheep and gesat industry would, no donbt, he able to ntie advantageonsly the lin rese non-irrigable areas." This sugrestion ean be trithfully applied to the whole arid land conntry from the llexican line to British America, and from the summit of the Carcade range in Oregon, to IV estern liansas and Nebraska. 
The present flocks and herds, said to number $24,0(x),(k)$ of steep and 1,201,00(0) cattle, in the arid land area could be greatly augutented, and an amomnt of additional value gathered from what is now desert that can hardly be conceived of. It is greatly to be hoped that the departments of Groverument will take measures to aid its present development, instead of creating and guarding solitudes. 1t is more than twelve years now, since the writer sugrested the nse of means to get artisian water onto these arid lands.

()n similar areas the governments of Anstralia are in ad. vance of ours, both in tlee reservation of forests and provisions for and conservation of watersupply. In New sontl IIales alone, the number of reserves aggregates 15.(50), distriluted over every connty and almost every parish in the province, in order to meet the needs of the people, ranging from 15 acres to $i t,(n k)$ acres in area. some of them are along the banks of rivers, extending two chains from the bank, apparently as protection from the tlood, wood and defris carried hy the streans when in extraordinary tlood, as sometimes ocenrs there as in some portions of arid Anerica. They are under a local board of controt, which tends to cul. tivate a public spirit-thongh sometimes so numerons as to create confusion. The report mentions thirty miles on one river as being in charge of no less than fourteen boards. There is no hint in the consular reports of the practical Auntralians creating permanent reserves of millions of acres of timberas protection to the thow of streans. The whole system seems to be snanaged for immediate practical devel. opment, suchas is greatly needed throughout onr arid land districts, in which there are now settlers who have to nee sagebrusl for fuel. From the report of Consul Canteron, of sydney, New sonth Wates, the following is taken: "It is worthy of note, the intluence of trees is comparatively "uil' in this country. During the exceptionally wet year of $1 k x$, on Dinly station, north of Baradine, for miles north of sydney, sitnated in a densely timbered conntry, the mean rainfall was 32.66 inches against 39.92 at the neighboring station in the open. On the other hand, in the very iry year of 1kst, Dinby fignred for 11.73 inches with 1.5 .59 inches at the a hovestations. Elevation, however, weens to have a heneficial intluence on rainfall, as the average of fourteen years at Wolfongong, half a mile from the sea, at a lieight of sixtyseven feet is 38.44 inches, and at Cordeanx, near the same place, six miles from the sea, it is 5.5 .53 inclies for seventeen year at an elevation of alsont 1,201 feet. " J'he foregoing exfract is uiven forwhat if may he worth as indicating whether it 
is the presence of the timber which influence precipitation. or elevation, merely, which has a [avorable effect in increasing rainfall. There are other points in Consul Camerou's excellent report that I shall call attention fo, namely, the amount of moisture taken up by evaporation by different soils and situations, but inore particularly the difference between sod-covered soil and bare earth and water surface. The test was made by Mr. H. C. Rusall, B. A. C. M. (i. F. R. $\therefore$, the government astronomer for New South Wales. The tests were secured by the use of pans eight inclies deep, and surfaces of four square feet and the records made when practicable thromgh the twelve monthis of the wettest sabon recorded, which showel a mean temperature of $63.1^{\circ}$, the

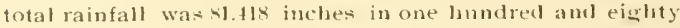
four days of the year, on many of which evaporation did not take place, the water running over the test pans. The total evaporation frotn the syluare in grasses was 3.5.hin inclies; from the water surface 31.027 inclies; from the garlen soil, which, though sandy, hardened when dry, it was 25.tats inches, showing, by a difference of nearly ten and a lialf inches, that either the inherent heat of the live grass, the increase of exposed surface by the grass blates, or the sponge-like atsorjtion of the hare earth, mate this difference. 11 is probable all three agencies were aperative, but there is a difference between the grass and the water surfacen. The grass griving off 1.933 inclies more 1 han water. This inlicates an effect of aboorption of heat hy the broken arface and color of the grass, and perhaps a reflection of heat from the surface of the water, an effect 1 claim an one reason why a solid snowbank will the longer in the open air mumelted than in thick timler or hrush near hy, an effect that every one familiar with the monutains can often see. ()ther intluences are present, namely it is warmer in tense timber in the winter seanon than in the open and while it is conler in the timber during the daylight in summer when the sun is shinning, it is warmer within a timber belt an at summer night than in the open. This is proven by the fact that eolel given off from the trobles of anow during the night in the summer montlis ofter canaces water to freeze in the open, when it does not do so in the nearloy timber. There is another and very important fact indicated by the difference of ten and a half inclues of water evaporation between the grass covered and the bare soit. during the days of one year on which evaporation took place. If the great evaporation was catused by the life anct color of the graso and the ine reased surface its blasces offered to the sinn's rayd we mat reason. 
ably expect the greatly increased surface of a growing forest will throw off a greater anwonnt of moisture hy evaporation than will a grass surface. The question whether this is so or not is most respectfully referred to the eninent body of scientists to which the forestry committee belongs, and to the national experiment stations generally. The writer believes science will find that trees not only extract water from a greater depth of earth than does grass, hut also give off during the growing season much more. The evaporation, we see by this table, was nearly thirty-six inches of sl.tlis that fell. Could experiment he hromght to the solution of the question, the prediction is ventured that it will prove that trees not only draw much more water from the soil than grisis lut that, drawing it from a greater depth of cooler earth, they scatter a irreater coolness from their leaves, and thus produce the yrateful shade and pint-scented breath of the forests we all delight in.

leaving this anbject for the present, 1 yluote again from the con-ul's report immeliately following the tables I lave sllmumarized. He says: "In addition to iny previons remarks lescriptive of the soil characteristics, it should be borne in mind that erery lleece of wool that is produced takes a percentage of potash and other fertile matter out of the soil, and that hitherto nothing has heen done to replace these elenents. As a consequence, valuable lierbage grabually gives out aud is replaced ly an inferioroutput. Forinstance, pine scruh has seizerl on thousinds of acres in the interior of "hat "as formerly magnificent pastoral land." The italics are mine. I don't believe Mr. Cameron has got the truecanse, though it may beso in som thinsoils in Australia. Pine scruls and that of yellow fir (Dom lats spruce) takes the land in eastern and western () regon where a fleece of wool or a pound of flesh never was extracted from the soil by domestic animals.

The consular report from which I lave just quoted contains unch that may be useful to the industries of eastern Oregon, which is the western edire of vast natural pasture lands of the range states, and of which ()regon yet has nearly thirty millions of acres east of the Cascade range, which, as yet, are neither reserved nor solk. For the certain developinent of these lands to the highest possible ase, hoth timber and water conservation a re necesatry under conditions which seem so nearly similar to those in New south IVales as to make the examples they set us in their methods of great value, as guides towards improving our own present methods. The report shows that the natural condition of 
eacli district has been closely studied as to the kind of stock it will hest support. Heary or light horses, heary or light cattle, cattle for the dairy, or cattle-breeding for beef-the districts hetter adapted to sheep than any of the larger stock, -these eminently practical people havecunalted the genius of each locality and devoted the land to the purpose for which nature best fits it. It also shows that not only private enterprise, but pulitic money is actively at work developing. the best means of gretting water onto the arid areas of that land, once thought impossible of use to civilization, as was the Great American desert of fifty years ago. In doing this the example set hy private enterprise in California in sinking artesian wello, is not only encouraged by public recosnition, but the government engages in the same business when private capital and enterprise are insulticient, doing such work as was suggested by the writer in a lefter to crosermor Yoody and hy him forwarded to senator J. N. [olph, and by himsubmitted to the appropriate committee of the ['nited States senate. The committee included in an appropriation bill a literal item to test the artesian well sytem in Colorallo and in Oregron, which was defeated, I think by monconcurrence of the homse of conderess.

The need of water on the vast body of the public clomain yet in the arid land states requires that neans should be taken to apdroxinastely measure the amonnt of water which does not tlow off by the river aystens, nor is yet aceonuted lor hy the ascertained evapuration. In this, common observation teaches that people of eastern Oregon are very seratly interested, becalase, on ancomint of the character of the surface formation, the precipitation falling east of the summit ridlse of the cascale range seems in larger measure to pasts into the ground where it falli-and ast on that ranereand interior momntains merely, hut over the great plasin of the Columbia basis. The disappearance of snow from the surface, wnder the inlluences of the (Chinook), wind from the pacific dean, leaving the ground try in a few minutes, seems to the olserver magical turning in a few lomes of

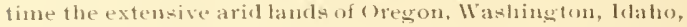
and western Yontana from a snow covered condition distressful for the stock owner to contemplate, into immecliately nablite pasture lands, yet showing little effect on the grat riser of the west-the colmombia the thoods of which ociur usually in June.

Where does this precipitation lodge; and is it recoverable for uses in agriculture and horticulture? are questions of

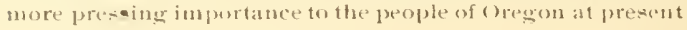


than the opening of the unnecessarily larec cascale forest reserve, on the eastern portion of which, pasturage beillg fermitted, the liventuck interest can have the benefit until a permanent forest policy (slionld one le neederl) can be adopted, which will minister to the areneral welfare. I luave endeavered to show that the privilege of grazing the east sicle of the Cascacle range and foothills is of the antual value of $\$ 1,0(x), 0(x)$. The entire value of the sheep and wonl interest of the state is shown in the Oregrmian of $\mathrm{January} 1$. la!h, to be as follows:-

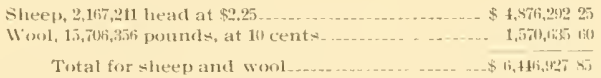

Nearly, or ynite, four-lifthy of the value is in the $1, x+i, 54$ ? sheep kept in the fonteen connties of bastern ()regon, where, as I have sild precipitation sinkis below the surface in a manner wur eastern friends, who pass resolutions to keep the nse of our forest lands from us, cannot pussibly understand. Conld these gentlemen become imbued with the knowledge Dr. Fernow gained hy his visit to Arizona last fall, and pereeive as he did the wonderful effects of water on the arid lands, which by the use of irrigation water will becone fields w production-yardens like that of Fdi-n

in which to srow "every tree that is pleasant to the sight and good for food," they would cease to injure us. To resalize Mr. Fernow's conception there is much more wecessity for the expenditure of public money, to inslicate to the people how to secure the water precipitated aluring the year, for nse in the growing season, than there is for a forestry policy, alleit the experiment station of [tall, by acting on I)r. Fernow's proposition for setting apart certain lands for testing the timber trees, singesested by limin order to find what is hest, is taking hold of the forestry guestion in a practical unaner. The experiment station's efforts to fincl how much irrigation water is required for the production of a quen crop is very commendable, as teaching how to make the desert blossom with the rose, in the very midst of the vast area, we now begin to see of valne that cannot yet be estimated: but which 1 believe will be increased, not dimiuislued, by the nse of sheep in pasturing all the timbered lighlanda interior to the Caseade range, as well as on its easternslopes.

To close this paper, I will smmuarize the position 1 helieve the closest possible scientific tests will demonstrate as true. 
First--Neither in the valleys nor on the mountains of Oregon are eithes sheep or cattle an injury to the growth of coniferous trees.

Second.- While the density of the forest growth which Oregon people deem commercial timber makes sheep keeping in it impossible, the grazing of the summit ridges and eastern slopes is heneficial and protective.

Third.-Snow melts first on those mountains within the timber, or on brish lands, to which 1 add, both timber atsd brush lands consume more water than they give ont (none of which is given out in any other way than from the leaves.) Trees lift the moisture from the earth while growing: the common observation of all wholave worked in maple-sugar camps teaches that there is a principle of life in a trec that causes the sap to run when the grasis plants are under suow. Still. snow Jying from winter till after the middle of July is incompatible with the rrowth of timber of value. The surface sources of streams are from anow in the open after that date. To this I will add that mo plant known to me dispenties water from its roots-all are drinkers; and when the question becomes so important as it is mow becominu-how to make homes of abundance on the yet unpurchased arid lands, it is letter to find ont, if it he findable by science, whether we have not all becn following "a general concen<l1s of opinion" which science will not sustain, loy believing that shade will increase the flow of a mountain stream as we were taught by the charming Ayrshire plowman, when be made the stream say:-

"last day l errat wil" spite and teen

When Poet Burns easm by

That to a baral $b$ should be seen

With hatf my chammel lry."

The conception of the poet was that the trees loy their shade would prevent evaporation of more moisture than there roots would take up. The forestry commitlee reasons on that hasis, but my olsorvation compels me 10 conclude that the shepherd ling of Israel was truer to nature than [Burna, and will be found trurer to science when lae saicl of at good man: "lle shall he like a tree planted by rivers of water that bringetlo forth his fruit in his season; his leaf also shall not wither" * * *-PMalms $1: 3$.

\section{APPENIXX}

In order to bring before the mind of interested reacters the ratio of evaporation, table No. IV of hulletin all of the C'tals 
experiment station is inserted as showing the results ob. tained by two kuropean scientists:

TABLE NO. IV.

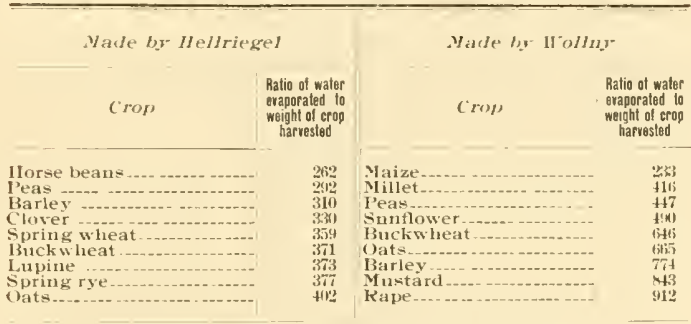

Accordiug to Ifellriegel, 330 tons of water would be ab. surbed by the roots of clover, drawn up through the stems and evaporated from the breathing pores of the leaves for each ton of clover harvested. If the yield he estimated at three tons per acre, the quantity of water per acre is (xy) ton:-, or a volume sufficient to cover the surface to a depth of $\forall-11$ feet, or nearly nine inches.

Helfreigel's resultsas to clover tends to explain why alfalfa, one of the strongest growing of the clover family, is "always dry," not unusually receiving sufficient over the surface during the growing meason in Ltah to cover the ground six feet. Should alfalfa te found to drink water by the roots in the same proportion as above claimed for clover the seven tons per year given as the yield in the snake River Canyou lead to the astonishing result of 2,310 tont of water per acre annually consumed, or about 27 inches, which is yet so far short of the six feet mentioned by Mr. Sammel Fortier, compiler of Bulletin ."4, on the "water supply of Cache valley, I'tah."

The difference sugrests such an immense waste of water where that may be so truly called "the water of life" as to call for a wide range of experiment, both as to the requirement of plants and economical methols of furnishing what is necessary.

In connection with Yr. Dosh's brief description of orchards and farmsof snake river canyon, the cultivator ought to know as near as possible low much water he needs for each acke of apples, pears, peaches, prunes or other fruit crop; how much for his several field crops. These questions will not 


\section{3}

only arise in limited localities, as between those who a re drawing from the same ditch, but will arise between districts as to what proportion of a river, like the Snake river, shall be drawn out on the north side, at the American falls for instance, and what amount will be required or can be used on the south side. So, in such a situation as the Deschutes near farewell hend, the whole flow of the river might be taken on to the desert, but on the west side the Tamilowa and lienton, or Squaw creek, can be used over much of that area, while the whole of the stream could be taken out on the east side and carried across Crooked river to fertilize in tine body of dry plain on the north side of that stream.

Therecertainly seems a wicle field for intelligent enter prise.

JoIN DINTO,

Secretary state hoard of llorticulture. 


.

$\checkmark$

$>$

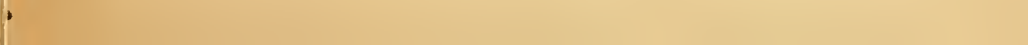


LIBRARY OF CONGRESS

H H H I I H H

(.). . . . . .

I. I. I. I. I. II. I. I. I. I.

00008798928 